\title{
The mode of action of dietary carbohydrate on protein metabolism
}

\author{
By H. N. MUNRO, J. G. BLACK and W. S. T. THOMSON \\ Department of Biochemistry, University of Glasgow \\ (Received 20 April 1959-Revised 18 fuly 1959)
}

It was recognized more than 60 years ago that administration of carbohydrate to fasting animals causes a fall in urinary nitrogen output, whereas the giving of fat does not have a similar effect (see review of literature by Munro, 195 I). In confirmation of this difference between the actions of carbohydrate and fat, the giving of glucose to fasting subjects causes a sharp and transient fall in blood amino-acid concentration, which does not occur after the administration of fat (Munro \& Thomson, 1953). Thus carbohydrate has some specific action on the protein metabolism of fasting animals, but, despite attempts at elucidation, the mechanism remains obscure (Munro, 195 I).

In the experiments now described we have tried to determine which tissues receive the amino acids removed from the plasma under the action of glucose. To do so, we have administered glucose to fasting rats and have observed its action on the $\mathrm{N}$ content of the liver and of the remainder of the body and on the distribution among the tissues of labelled amino acids given by injection. From the findings we have concluded that muscle is the primary site of the protein-sparing action of carbohydrate. A preliminary report of these findings has already appeared (Black, Munro \& Thomson, I956).

\section{EXPERIMENTAL}

\section{Nitrogen-retention studies}

Animals. Male albino rats of about $250 \mathrm{~g}$ weight were distributed between the various experimental groups by the randomized-block technique, to reduce the statistical effects of differences in body-weight (Snedecor, 1946). They were housed individually at constant temperature in glass containers which also served for the collection of excreta (Thomson \& Munro, I955).

Diets and collection of urine. During a preliminary period the rats received a synthetic diet (Munro \& Naismith, I953) given to supply approximately I $200 \mathrm{kcal} / \mathrm{m}^{2}$ body surface area/day. Some animals received adequate amounts of protein in this diet $(3 \circ \mathrm{g}$ casein/day); others were given the diet with all the protein replaced by carbohydrate. After 6 days, the rats on each diet were divided into three groups. One group was fasted for $24 \mathrm{~h}$, the second group was given $12 \mathrm{~g}$ glucose and the third group received only $5 \mathrm{ml}$ olive oil. During this $24 \mathrm{~h}$ period, urine was collected with the apparatus described by Thomson \& Munro (1955). At the end of the $24 \mathrm{~h}$ period, the animals were killed by exsanguination under ether anaesthesia and the livers were excised. 
Analysis of urine and liver. The urine was analysed for $\mathrm{N}$ by the micro-Kjeldahl procedure, mercury being used as the catalyst (Munro \& Naismith, 1953). The liver was homogenized in water with a top-drive blender (Measuring and Scientific Equipment Ltd) and a portion of the homogenate taken for determination of total N. The remainder was retained for estimation of protein content by precipitation with trichloroacetic acid (TCA), followed by extraction with fat solvents (Munro \& Naismith, 1953). The $\mathrm{N}$ content of the resulting dry powder was estimated and a correction for $\mathrm{N}$ contributed by nucleic acids in the powder was obtained by determining the total phosphorus content of the powder by the method of Allen (1940) and multiplying the figure by $\mathrm{I} \cdot 69$.

\section{Studies with labelled amino acids}

The effect of glucose administration on the deposition of $\left[{ }^{35} \mathrm{~S}\right]$ methionine, $\left[{ }^{14} \mathrm{C}\right]-$ glycine and $\left[{ }^{14} \mathrm{C}\right]$ leucine in various tissues was examined.

Animals. Young adult male albino rats were fasted for $24 \mathrm{~h}$ and those weighing close to $200 \mathrm{~g}$ were selected. These were then injected intraperitoneally with $20 \mu \mathrm{c}$ of DL- $\left[{ }^{35} \mathrm{~S}\right]$ methionine or $\left[2-{ }^{14} \mathrm{C}\right]$ glycine or with $10 \mu \mathrm{C}$ of DL- $\left[\mathrm{I}-{ }^{-14} \mathrm{C}\right]$ leucine in $\mathrm{I} \mathrm{ml}$ of $0.9 \% \mathrm{NaCl}$ solution. After an interval of $0.5 \mathrm{~h}$ to allow the labelled amino acid to be absorbed from the peritoneal cavity, the animals were given by stomach tube either $4 \mathrm{ml}$ of a $50 \%$ (w/v) glucose solution, I $\mathrm{ml}$ olive oil, or $4 \mathrm{ml}$ water (control group). At $\mathrm{I}, 2,4$ or $6 \mathrm{~h}$ after this meal, they were killed by a blow on the head, and samples of liver and of thigh muscle, and in some instances of intestinal mucosa and of diaphragm, were taken for determination of radioactivity. The intestinal mucosa was obtained by scraping the inner surface of the cleaned small intestine. The fibrous central tendon of the diaphragm was discarded.

Treatment of tissue samples. The liver and intestinal mucosa were homogenized in $20 \mathrm{ml}$ of $30 \%(\mathrm{w} / \mathrm{v})$ ice-cold TCA in a blender. In all experiments with labelled methionine, and in the earlier experiments with $\left[{ }^{14} \mathrm{C}\right]$ glycine, protein was prepared from the muscle samples by the method of Sinex, McMullen \& Hastings (1952). The enzymes were first inactivated by immersion of the portion of muscle in O. I N- $\mathrm{H}_{2} \mathrm{SO}_{4}$, followed by homogenization in the blender in $20 \mathrm{ml}$ of $0.4 \mathrm{~N}-\mathrm{NaOH}$ for 15 min. After frothing had subsided, the protein was precipitated by addition of $30 \% \mathrm{TCA}$. In later experiments with $\left[{ }^{14} \mathrm{C}\right]$ glycine and in those with $\left[{ }^{14} \mathrm{C}\right] l e u c i n e$, the muscle was rapidly minced with scissors and then homogenized in $10 \%$ ice-cold TCA without preliminary treatment with alkali.

The TCA precipitates obtained from these various organs were then washed twice with $10 \%$ ice-cold TCA and finally heated for $15 \mathrm{~min}$ in $10 \% \mathrm{TCA}$ to remove nucleic acids (Schneider, 1945). The insoluble residue was dissolved in $0.4 \mathrm{~N}-\mathrm{NaOH}$, the solution reprecipitated with $30 \% \mathrm{TCA}$ and the precipitate separated by centrifugation. This procedure has been recommended by Melchior \& Halikis (1952) for the removal of free amino acids trapped in the protein precipitate, and was carried out twice on each sample.

The precipitated protein was then washed successively with $20 \mathrm{ml}$ portions of the following fat solvents: $95 \%(\mathrm{v} / \mathrm{v})$ ethanol (twice), ethanol-chloroform ( $3: \mathrm{I})$, ethanolether $(3: 1)$, absolute ethanol, and ether. The protein was finally separated from the ether suspension by filtration through a Hirsch funnel. 
Measurements of radioactivity on samples of whole protein. After injection of $\left[{ }^{14} \mathrm{C}\right]-$ glycine and $\left[{ }^{14} \mathrm{C}\right]$ leucine, the protein samples were counted without isolation of the labelled amino acids. The protein sample, dried from ether, was finely ground in a glass mortar and counted at infinite thickness on a Polythene planchet $1 \mathrm{~cm}$ in diameter, with an end-window Geiger-Müller tube. The activity was expressed as counts/min/planchet (specific activity).

Isolation of methionine from protein. The dried, fat-extracted protein (100 $\mathrm{mg}$ ) was refluxed under $\mathrm{N}_{2}$ in $6 \mathrm{~N}-\mathrm{HCl}$ for $8 \mathrm{~h}$ (Kassell \& Brand, 1938). The $\mathrm{HCl}$ was removed by distillation under reduced pressure and the residue taken up in distilled water. Methionine was then isolated from the hydrolysate and counted by a method that will be published later. This method involved precipitation of cystine as the copper salt (Zittle \& O'Dell, I94I), oxidation of methionine in the oxygen bomb and isolation of the inorganic sulphate formed as benzidine sulphate (Young, Edson \& McCarter, I949). The latter was then assayed for radioactivity with an end-window GeigerMüller tube. The activity was expressed as counts $/ \mathrm{min} / \mathrm{mg}$ methionine $\mathrm{S}$ (specific activity).

Isolation of free glycine from the cell. The supernatant fluid obtained when the proteins of the tissues were precipitated with TCA was collected and washed with ether until the $\mathrm{pH}$ rose to 4 . The aqueous phase was then dried under reduced pressure, the residue taken up in a small quantity of water and allowed to react with fluorodinitrobenzene to yield dinitrophenylglycine, as described by Clark, Naismith \& Munro (1957). The radioactivity of the product was then assayed as described by these authors and expressed as counts/min/ roo $\mu \mathrm{g}$ glycine (specific activity). The purity of the dinitrophenylglycine finally isolated was periodically checked by ascending paper chromatography with tertiary amyl alcohol as the developing solvent (Blackburn \& Lowther, I95 I). It was also established that the use of $0.4 \mathrm{~N}-\mathrm{NaOH}$ in preparing the muscle homogenate before precipitation with TCA (see above) did not affect the specific activity of the glycine subsequently isolated from the TCA extract.

\section{RESULTS}

\section{Nitrogen-retention studies}

As is well known, the giving of glucose to fasting animals of various species causes a reduction in urinary output of $\mathrm{N}$ (see review by Munro, 195 $\mathrm{r}$ ). Table $\mathrm{I}$ demonstrates that this response also occurs in the rat, since the giving of glucose for $24 \mathrm{~h}$ resulted in a lower $\mathrm{N}$ output than occurred during fasting or after the giving of fat. Analysis of the liver at the end of the $24 \mathrm{~h}$ period showed, however, that the retained $\mathrm{N}$ was not deposited in that organ; instead, its $\mathrm{N}$ content was reduced owing to a fall in liver protein (Table I). These findings were evaluated statistically by analysis of variance. Since the responses of urinary $\mathrm{N}$ and liver $\mathrm{N}$ to carbohydrate and fat administration were not significantly influenced by the protein content of the preceding $\operatorname{diet}(P>0.05$ for interaction), the results obtained at the two levels of protein intake can be considered together. The diet given during the final $24 \mathrm{~h}$ period was shown to have a significant effect on urinary $\mathrm{N}$ output $(P<0.0 \mathrm{I})$, on total liver $\mathrm{N}(P<0.05)$ and on 
liver protein $(P<0.05)$. From the error variances obtained in the statistical analyses, the minimum values needed to establish a significant difference between groups of rats were computed (Snedecor, 1946), and the changes produced by carbohydrate and by fat administration were compared with these values (Table $\mathrm{I}$ ). The giving of glucose caused a depression in urinary output of $\mathrm{N}$ which exceeded the $\mathrm{I} \%$ level of significance, whereas the reduction in $\mathrm{N}$ output after giving fat just exceeded the $5 \%$ level of significance. The total $\mathrm{N}$ content and the protein content of the liver were reduced by administration of glucose, but not by administration of fat. The reduction in total $\mathrm{N}$ content did not differ significantly from the mean value obtained with the fasting group, but was significantly different from the value obtained with the group given fat. The giving of carbohydrate reduced the protein content of the liver significantly below the level observed in the fasting group and in the group given fat.

\section{Table I. Urinary nitrogen output and liver nitrogen content of rats after they had received carbohydrate or fat for $24 h$}

(After a 6-day preliminary period on diets adequate in protein or free from protein, the rats were either fasted or given $12 \mathrm{~g}$ glucose or $5 \mathrm{ml}$ olive oil over a $24 \mathrm{~h}$ period, during which urine was collected. Each entry in the table is the mean value for six animals)

$$
\begin{gathered}
\text { Diet during } \\
\text { preliminary } \\
\text { period }
\end{gathered}
$$

With adequate protein

Protein-free

Statistical analysis of results :

Difference from fasted groups*

\begin{tabular}{|c|c|c|}
\hline \multicolumn{3}{|c|}{ Nitrogen } \\
\hline$\underset{\substack{\text { In } \\
\text { urine } \\
(\mathrm{mg} / 24 \mathrm{~h})}}{.}$ & $\begin{array}{l}\text { Total in } \\
\text { liver } \\
\text { (mg/rat) }\end{array}$ & $\begin{array}{l}\text { In liver } \\
\text { protein } \\
\text { (mg/rat) }\end{array}$ \\
\hline 180 & 204 & I4I \\
\hline 127 & 199 & 135 \\
\hline 147 & 209 & I 44 \\
\hline 90 & 185 & I3I \\
\hline $5^{8}$ & 175 & II 6 \\
\hline 74 & 192 & 129 \\
\hline-43 & -8 & $-I I$ \\
\hline-24 & +6 & +1 \\
\hline 23 & I 1 & 10 \\
\hline 3 I & 14 & $\mathbf{r} 3$ \\
\hline
\end{tabular}

Minimum significant difference

* Based on the combined results for the rats given the diet adequate in protein and those given the protein-free diet.

Since a tissue or tissues other than the liver must thus be responsible for the retention of $\mathrm{N}$ occurring after glucose administration, further exploration was made by injecting labelled amino acids and determining the effect of glucose administration on their distribution among different tissues.

\section{Experiments with labelled amino acids}

Studies with $\left[{ }^{35}\right.$ S $]$ methionine. Rats were injected with $\left[{ }^{35}\right.$ S] methionine and given glucose, olive oil or water (controls) $0.5 \mathrm{~h}$ later. They were killed at various time intervals up to $6 \mathrm{~h}$ after feeding and the uptake of labelled methionine was determined in several organs. The specific activity of methionine isolated from the proteins of different organs differed considerably (Fig. I), that of the intestinal mucosa being 
greater than that of the liver, which in turn was greater than that of muscle. Similar findings with $\left.{ }^{35} \mathrm{~S}\right]$ methionine have been reported by Friedberg, Tarver \& Greenberg (I948). It is also apparent from Fig. I that the general level of incorporation into the diaphragm was about twice that into leg muscle; using $\left[{ }^{14} \mathrm{C}\right]$ glycine, Altman, Casarett, Noonan \& Salomon (1949) also observed a greater incorporation of this labelled amino acid into the diaphragm than into other muscles.

The effect of carbohydrate and fat administration on $\left.{ }^{35} \mathrm{~S}\right]$ methionine incorporation by the proteins of the intestinal mucosa, liver and muscle was evaluated statistically by analysis of variance. There was no significant effect of feeding with glucose or with olive oil on the uptake of $\left[{ }^{35} \mathrm{~S}\right]$ methionine by the proteins of intestinal mucosa or of liver $(P>0.05)$. For the diaphragm and leg muscle, however, the animals given glucose differed significantly from those given water or fat. Two hours after feeding, the
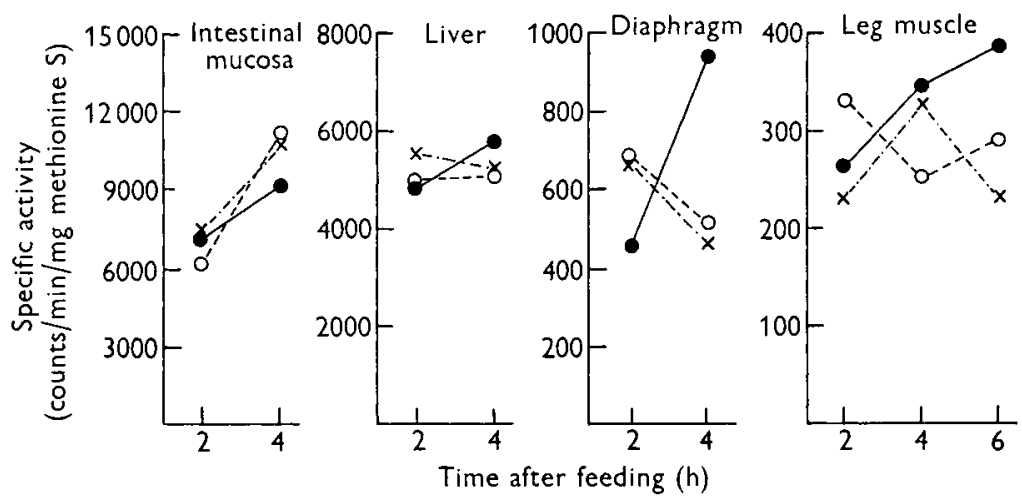

Fig. I. Specific activity of methionine in the proteins of the intestinal mucosa, liver, diaphragm and leg muscle after administration of water $(0-\cdots)$, glucose $(-\bullet)$ or olive oil $(x-\cdots \times)$ to rats previously injected intraperitoneally with $\left[{ }^{35} \mathrm{~S}\right]$ methionine. Each point on the graph represents the mean result obtained with two rats for the intestinal mucosa, four rats for the liver and five rats for the diaphragm and leg muscle.

glucose-fed rats showed somewhat less incorporation of $\left[{ }^{35} \mathrm{~S}\right]$ methionine than did those in the other groups, but at $4 \mathrm{~h}$ and in leg muscle at $6 \mathrm{~h}$, the glucose-fed group exhibited a significantly higher uptake of the labelled amino acid $(P<0.05$ for the effect of treatment on specific activity). Though these results suggest a specific action of glucose on protein metabolism in muscle, their interpretation remains equivocal. The more intense radioactivity in the muscles of the glucose-fed animals could be due to increased protein synthesis, or it could represent greater labelling of the methionine in the amino-acid pool of muscle from which the proteins are synthesized. Measurements of the radioactivity of methionine in the free amino-acid pool seemed likely to present difficulties, and we therefore turned to $\left[{ }^{14} \mathrm{C}\right]$ glycine in order to study the effect of glucose administration on the free amino-acid pool.

Studies with $\left[{ }^{14} \mathrm{C}\right]$ glycine. When animals were injected with $\left[2-{ }^{14} \mathrm{C}\right]$ glycine and then given glucose, the same picture emerged as that obtained with $\left.{ }^{[35} \mathrm{S}\right]$ methionine. One hour after glucose administration, the muscle proteins had taken up less radioactivity than after administration of water, but thereafter radioactivity in the muscle protein 
of the glucose-fed group rose more rapidly than that of the control group (Table 2). Liver protein did not share in this response. The specific action of glucose on muscle is best seen when glycine uptake by muscle protein is expressed relative to uptake by liver protein (Table 2). The radioactivity of muscle protein relative to liver protein increased more rapidly after glucose administration than after administration of water; the difference between the two groups (last column of Table 2) showed a significant positive linear regression in relation to time after feeding $(P<0.02)$.

\section{Table 2. Effect of glucose administration to rats on uptake of $\left[{ }^{14} \mathrm{C}\right] \mathrm{g}$ lycine by the proteins of muscle and liver}

(Rats received by stomach tube $4 \mathrm{ml}$ of $50 \%(\mathrm{w} / \mathrm{v})$ glucose or $4 \mathrm{ml}$ water $0.5 \mathrm{~h}$ after intraperitoneal administration of $10 \mu \mathrm{c}$ of $\left[2-{ }^{14} \mathrm{C}\right]$ glycine/100 $\mathrm{g}$ body-weight. Each entry is the mean value with its standard error for four rats)

\begin{tabular}{|c|c|c|c|c|c|c|c|}
\hline \multirow[b]{2}{*}{$\begin{array}{l}\text { Time } \\
\text { after } \\
\text { feeding } \\
\text { (h) }\end{array}$} & \multicolumn{2}{|c|}{$\begin{array}{l}\text { Specific activity of } \\
\text { muscle protein } \\
\text { (counts/min/planchet) }\end{array}$} & \multicolumn{2}{|c|}{$\begin{array}{c}\text { Specific activity of } \\
\text { liver protein } \\
\text { (counts/min/planchet) }\end{array}$} & \multicolumn{3}{|c|}{$\frac{\text { Specific activity of muscle protein }}{\text { Specific activity of liver protein }} \times 100$} \\
\hline & $\begin{array}{l}\text { Rats } \\
\text { given } \\
\text { water }\end{array}$ & $\begin{array}{l}\text { Rats } \\
\text { given } \\
\text { glucose }\end{array}$ & $\begin{array}{l}\text { Rats } \\
\text { given } \\
\text { water }\end{array}$ & $\begin{array}{l}\text { Rats } \\
\text { given } \\
\text { glucose }\end{array}$ & $\begin{array}{l}\text { Rats } \\
\text { given } \\
\text { water }\end{array}$ & $\begin{array}{l}\text { Rats } \\
\text { given } \\
\text { glucose }\end{array}$ & Difference \\
\hline I & $66 \pm 9$ & $46 \pm$ II & $2186 \pm 20 r$ & $1930 \pm 326$ & $3.19 \pm 0.66$ & $2.54 \pm 0.24$ & -0.65 \\
\hline 2 & $78 \pm 2$ & $85 \pm 12$ & $1982 \pm 273$ & $1914 \pm 160$ & $4.14 \pm 0.46$ & $4 \cdot 39 \pm 0.29$ & +0.25 \\
\hline 4 & $96 \pm$ I0 & $105 \pm 10$ & $2205 \pm 35$ & $2091 \pm 298$ & $4.36 \pm 0.46$ & $5.16 \pm 0.45$ & +0.80 \\
\hline 6 & II $8 \pm 9$ & $138 \pm 7$ & $2191 \pm 122$ & $2046 \pm I 22$ & $5.43 \pm 0.44$ & $6.78 \pm 0.34$ & $+I \cdot 35$ \\
\hline
\end{tabular}

With $\left[{ }^{14} \mathrm{C}\right] g l y c i n e$, it was possible to study the effect of glucose administration on radioactivity in the free amino-acid pools of liver and muscle. After glucose administration, the specific activity of the free glycine of the muscles increased above the level found in the liver (Fig. 2); this effect was not produced by water or olive oil. The specific effect of glucose on the glycine pool of muscle was explored more fully with a larger series of animals. This experiment showed that the ratio of the specific activity of the free glycine of the muscle to that of the liver increased steadily with time after injection in the groups given water or glucose (Fig. 3), but the ratio was significantly greater for the latter group $(P<0 \cdot 0 \mathrm{r}$ by analysis of variance). A difference between the two groups was already evident $2 \mathrm{~h}$ after glucose administration, and at $6 \mathrm{~h}$ the ratio for the animals given glucose was about $50 \%$ greater than the ratio for the animals given water. This increase in the radioactivity of the free amino-acid pool on administration of glucose seems adequate to account for the observed increment in glycine uptake by muscle protein (Table 2) without the need to postulate a change in the rate of protein synthesis.

Studies with $\left[{ }^{14} \mathrm{C}\right]$ leucine. In a few experiments, uptake of $\mathrm{DL}-\left[\mathrm{I}-{ }^{14} \mathrm{C}\right]$ leucine by the proteins of liver and muscle was examined at $\mathrm{I}$ and $2 \mathrm{~h}$ after the giving of glucose or water (Table 3 ). When the results are expressed as uptake by muscle protein relative to uptake by liver protein, preferential deposition of the amino acid in muscle after administration of glucose is apparent at both time intervals. This action of glucose is significant $(P<0.05$ by analysis of variance) and occurs at a much earlier time than 

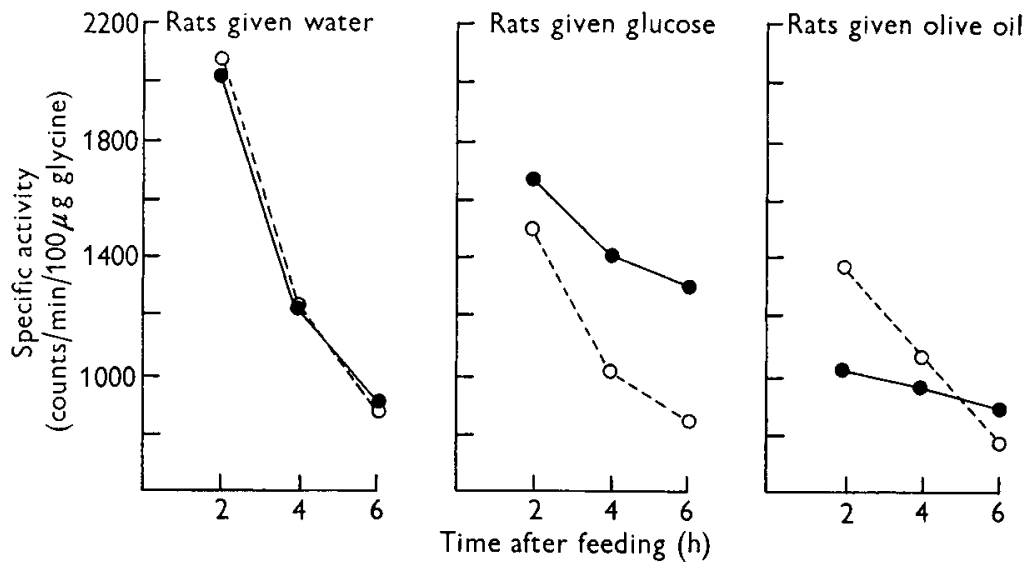

Fig. 2. Specific activity of glycine in the free amino-acid pool of muscle (-- ) and of liver (0---0) after administration of water, glucose or olive oil to rats previously injected intraperitoneally with $\left[2-{ }^{14} \mathrm{C}\right]$ glycine. Each point on the graph represents the mean result obtained with three rats.

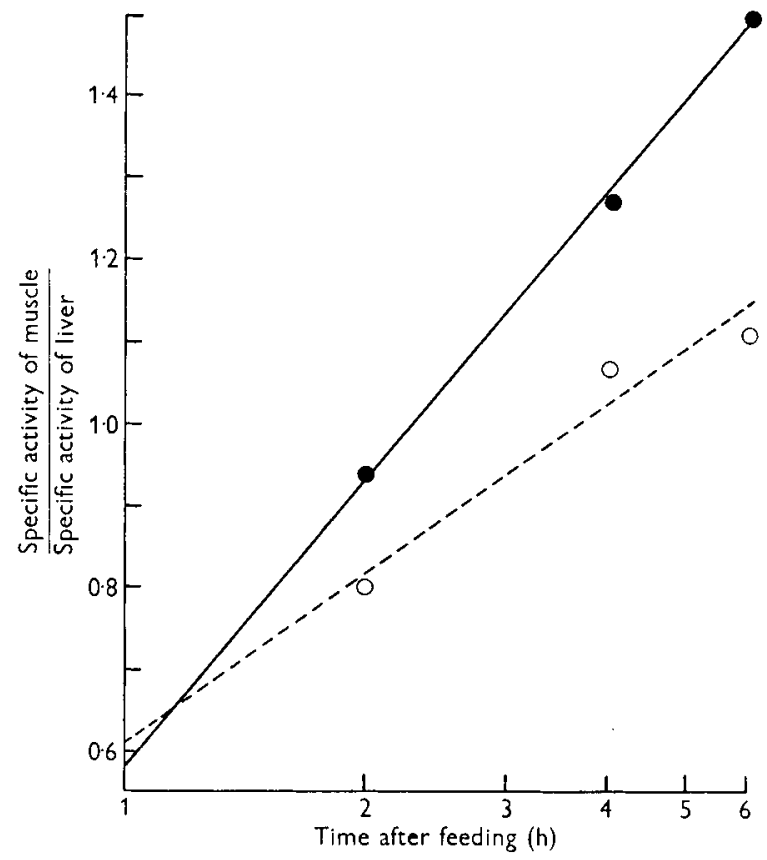

Fig. 3. Changes in the specific activity of glycine in the free amino-acid pool of muscle relative to that of liver after administration of glucose $(-\bullet)$ or water $\left(0_{--0}\right)$ to fasting rats previously injected intraperitoneally with $\left[2-{ }^{14} \mathrm{C}\right]$ glycine. The results are described by the equations $y=0 \cdot 5^{8}+$ $1 \cdot 20 x$ for animals given glucose, and $y=0.61+0.70 x$ for animals given water, where $x$ is the log of the time $(h)$ since feeding and $y$ is the ratio of the specific activity of free glycine in the muscle to that of free glycine in the liver of the same animal. Each point on the graph represents the mean result obtained with five animals. 
the increase in labelling observed with $\left[{ }^{35} \mathrm{~S}\right]$ methionine or $\left[{ }^{14} \mathrm{C}\right]$ glycine. Since we did not measure the activity of $\left[{ }^{14} \mathrm{C}\right]$ leucine in the free amino-acid pool, we cannot say whether the greater incorporation into muscle protein after glucose administration coincides with increased labelling in the free amino-acid pool of muscle, as with $\left[{ }^{14} \mathrm{C}\right]$ glycine.

\section{Table 3. Effect of glucose administration to rats on uptake of $\left[{ }^{14} C\right]$ leucine by muscle protein relative to liver protein}

(Rats received by stomach tube $4 \mathrm{ml}$ of $50 \%$ glucose or $4 \mathrm{ml}$ water $0.5 \mathrm{~h}$ after intraperitoneal administration of $5 \mu \mathrm{c}$ of $\mathrm{DL}-\left[\mathrm{I}^{14} \mathrm{C}\right]$ leucine/ $100 \mathrm{~g}$ body-weight. Two experiments were done at each time interval; each entry is the result obtained with one rat)

\begin{tabular}{|c|c|c|c|c|}
\hline \multirow{2}{*}{$\begin{array}{c}\text { Time } \\
\text { after } \\
\text { feeding } \\
\text { (h) }\end{array}$} & \multirow[b]{2}{*}{$\begin{array}{l}\text { Expt } \\
\text { no. }\end{array}$} & \multicolumn{3}{|c|}{$\frac{\text { Specific activity of muscle protein }}{\text { Specific activity of liver protein }} \times 100$} \\
\hline & & $\begin{array}{l}\text { Rats given } \\
\text { water }\end{array}$ & $\begin{array}{l}\text { Rats given } \\
\text { glucose }\end{array}$ & $\begin{array}{c}\text { Mean } \\
\text { difference* }\end{array}$ \\
\hline $\mathbf{I}$ & $\begin{array}{l}1 \\
2\end{array}$ & $\begin{array}{l}4 \cdot 4 \\
6 \cdot 6\end{array}$ & $\left.\begin{array}{l}6 \cdot 7 \\
8 \cdot 1\end{array}\right\}$ & $+1 \cdot 9$ \\
\hline 2 & $\begin{array}{l}\text { I } \\
2\end{array}$ & $\begin{array}{r}6 \cdot 4 \\
10 \cdot 0\end{array}$ & $\left.\begin{array}{r}7 \cdot 3 \\
11 \cdot 4\end{array}\right\}$ & $+1 \cdot 2$ \\
\hline
\end{tabular}

* When the two time intervals are combined, the mean difference is $+1 \cdot 5$, with a standard error of $\pm 0 \cdot 3$.

\section{DISCUSSION}

When carbohydrate is given to fasting animals, there is a rapid but transient fall in blood amino-acid level and at the same time the urinary output of $\mathrm{N}$ decreases (Munro, 195 I). The giving of fat does not produce similar changes. The investigation described here was an attempt to explore the mechanism underlying this specific action of carbohydrate on protein metabolism. As a first step in determining where amino acids are deposited after carbohydrate administration, glucose was given to rats for $24 \mathrm{~h}$ and the changes in urinary output of $\mathrm{N}$ were compared with the changes in liver composition. Although the giving of glucose caused a reduction in urinary output of $\mathrm{N}$, protein was at the same time lost from the liver (Table $\mathrm{I}$ ). This observation is in agreement with previous experiments on rats (Munro \& Naismith, 1953) in which the energy content of a protein-free diet was increased by addition of either carbohydrate or fat to the diet. An improvement in $\mathrm{N}$ balance was observed only when carbohydrate was the additional source of energy, but this gain in body $\mathrm{N}$ was accompanied by a loss of liver protein.

Since none of the retained $N$ could be accounted for as liver protein, the effect was studied of glucose administration on deposition of amino acids in different tissues. Evidence of preferential deposition in muscle protein after administration was obtained with each of the three amino acids used. With $\left[{ }^{14} \mathrm{C}\right]$ leucine, uptake by muscle protein was increased i $h$ after the giving of glucose (Table 3 ), which corresponds to the period when the blood amino-acid level of the rat is falling most rapidly after carbohydrate administration (Munro \& Thomson, 1953). On the other hand, an increased deposition of $\left[{ }^{35} \mathrm{~S}\right]$ methionine and of $\left[{ }^{14} \mathrm{C}\right]$ glycine in muscle protein was not observed until $2 \mathrm{~h}$ or more after the giving of glucose (Fig. I and Table 2 ). With $\left[{ }^{14} \mathrm{C}\right]$ glycine 
we showed that the increase in radioactivity of muscle protein coincides with an increment in the specific activity of the glycine in the free amino-acid pool of muscle (Figs. 2 and 3 ), and we conclude that the changes in labelling of muscle protein do not necessarily imply increased protein synthesis. Although no explanation can be offered of why the responses observed with glycine and methionine should differ in rate of development from that with leucine, it should not be allowed to obscure the fact that, with all three amino acids, administration of carbohydrate produced a change in muscle not found in the liver.

The action of administered glucose on the amino-acid level in the blood appears to involve the secretion of insulin, since no reduction in level occurs in rats with alloxan diabetes (Munro, 1956) or in pancreatectomized dogs (Bollman, Flock, Grindlay, Mann \& Block, 1953). In confirmation, several authors showed that blood amino-acid level is reduced by administration of insulin (Luck, Morrison \& Wilbur, 1928; Kerr \& Krikorian, 1929; Powers \& Reis, 1933; Harris \& Harris, I947; Lotspeich, 1949). The viscera are not essential for this action of insulin since it occurs in eviscerated animals (Mirsky, 1938; Frame \& Russell, 1946; Ingle, Prestrud \& Nezamis, 1947). Furthermore, the reduction in blood amino-acid level takes place within $15 \mathrm{~min}$ of the giving of insulin to the eviscerated rat (Ingle, Torralba \& Flores, I956), a time interval commensurate with the speed of action of insulin on carbohydrate metabolism in muscle but not in liver (Renold, Hastings, Nesbett \& Ashmore, 1955). It is thus likely that muscle is the primary site of action of insulin on protein metabolism. This view received some support from the in vitro studies of Krahl (1953), who observed that incorporation of $\left[{ }^{14} \mathrm{C}\right]$ glycine by diaphragms taken from rats receiving an adequate diet was increased by addition of insulin to the medium, whereas liver slices from the same animals did not respond to insulin. A claim that insulin accelerates protein synthesis in the isolated perfused liver (Prudden, Young \& Stirman, 1956) conflicts with the negative results obtained by Miller, Burke \& Haft (1956) who used the same type of preparation. A more detailed consideration of the action of insulin on protein metabolism has been published elsewhere (Munro, 1956).

If we assume that muscle is the major tissue in which amino acids are deposited after glucose administration, the following can be offered as the most probable sequence of events. First, in response to carbohydrate administration, there is secretion of insulin, which leads to deposition of amino acids in some form in muscle. This deposit causes a reduction of the amino-acid level in the blood and as a result the supply of amino acids to other tissues is curtailed, with two consequences, $(a)$ urea production by the liver is reduced (protein-sparing action), and (b) tissues other than muscle have a diminished supply of amino acids for protein synthesis. This latter effect is shown in our experiments by a significant reduction in the protein content of the liver after administration of carbohydrate for $24 \mathrm{~h}$ (Table $\mathrm{r}$ ). A similar effect on formation of red cells is the most likely explanation of the finding that blood regeneration occurs more rapidly in fasting dogs than in dogs receiving a carbohydrate diet (Whipple, Hooper \& Robscheit, 1920). Finally, it may be pointed out that this reciprocal relationship between muscle and other tissues of the body may help to explain other metabolic phenomena. For example, cortisone causes a loss of protein from the peripheral 
tissues which is accompanied by a gain in liver protein (Silber \& Porter, 1953). This effect has been ascribed to utilization by the liver of amino acids arising from breakdown of muscle protein (Goodlad \& Munro, 1959).

\section{SUMMARY}

I. The mechanism by which administered carbohydrate causes a reduction in blood amino-acid level and in urinary output of nitrogen was investigated in rats by studying the changes in the distribution of $\mathrm{N}$ and labelled amino acids in different tissues.

2. The urinary $\mathrm{N}$ output of rats that had been fed for $24 \mathrm{~h}$ on glucose was markedly diminished as compared with the output of animals fed on olive oil or fasted, but none of the retained $\mathrm{N}$ was deposited in the liver, which on the contrary contained significantly less protein than in the other two groups.

3. Rats were injected with labelled amino acids and their deposition in the proteins of liver, intestinal mucosa and muscle was studied. Compared with animals receiving water or olive oil, rats given glucose showed enhanced incorporation of labelled amino acids into muscle protein. With $\left[{ }^{14} \mathrm{C}\right]$ glycine, it was accompanied by increased radioactivity in the free amino-acid pool of muscle.

4. It is suggested that secretion of insulin after glucose administration causes deposition of amino acids in muscle. This deposition curtails the supply of amino acids available to other tissues, so that protein synthesis by these organs and urea formation are diminished.

We gratefully acknowledge a grant for materials to one of us (H.N.M.) from the Medical Research Council, who also provided a Studentship for another of us (J. G. B.). The third (W.S.T.T.) was awarded a Hansen Scholarship by the University of Glasgow.

\section{REFERENCES}

Allen, R. J. L. (1940). Biochem. F. 34, 858 .

Altman, K. I., Casarett, G. W., Noonan, G. R. \& Salomon, K. (1949). Arch. Biochem. 23, I3 I.

Black, J. G., Munro, H. N. \& Thomson, W. S. T. (1956). Proc. Nutr. Soc. 15, vii.

Blackburn, S. \& Lowther, A. G. (195I). Biochem. F. 48, I26.

Boliman, J. L., Flock, E. V., Grindlay, J. H., Mann, F. C. \& Block, M. A. (1953). Amer. F. Physiol. I74, 467 .

Clark, C. M., Naismith, D. J. \& Munro, H. N. (1957). Biochim. biophys. Acta, 23, 587.

Frame, E. G. \& Russell, J. A. (1946). Endocrinology, 39, 420.

Friedberg, F., Tarver, H. \& Greenberg, D. M. (1948). F. biol. Chem. 173, 355.

Goodlad, G. A. J. \& Munro, H. N. (1959). Biochem. F. 73, 343.

Harris, M. M. \& Harris, R. S. (1947). Proc. Soc. exp. Biol., N. Y., 64, 471.

Ingle, D. J., Prestrud, M. C. \& Nezamis, J. E. (1947). Amer. F. Physiol. 150, 682.

Ingle, D. J., Torralba, G. \& Flores, V. (1956). Endocrinology, 58, 388 .

Kassell, B. \& Brand, E. (1938). F. biol. Chem. 125, 435.

Kerr, S. E. \& Krikorian, V. H. (1929). F. biol. Chem. 8x, 421.

Krahl, M. E. (1953). F. biol. Chem. 200, 99.

Lotspeich, W. D. (1949). F. biol. Chem. 179, 175.

Luck, J. M., Morrison, G. \& Wilbur, L. F. (1928). F. biol. Chem. 77, I5 5 .

Melchior, J. B. \& Halikis, M. N. (1952). F. biol. Chem. 199, 773.

Miller, L. L., Burke, W. T. \& Haft, D. E. (1956). In Some Aspects of Amino Acid Supplementation, p. 44. [W. H. Cole, editor.] New Brunswick: Rutgers University Press. 
Mirsky, I. A. (1938). Amer. F. Physiol. 124, 569.

Munro, H. N. (1951). Physiol. Rev. 31, 449.

Munro, H. N. (I956). Scot. med. F. r, 285.

Munro, H. N. \& Naismith, D. J. (1953). Biochem. F. 54, I91.

Munro, H. N. \& Thomson, W. S. T. (1953). Metabolism, 2, 354.

Powers, H. H. \& Reis, F. (1933). F. biol. Chem. ror, 523.

Prudden, J. F., Young, M. K. Jr. \& Stirman, J. A. (1956). F. Lab. clin. Med. 47, 370.

Renold, A. E., Hastings, A. B., Nesbett, F. B. \& Ashmore, J. (1955), F. biol. Chem. $213,135$.

Schneider, W. C. (1945). F. biol. Chem. r6r, 293.

Silber, R. H. \& Porter, C. C. (1953). Endocrinology, 52, 5 I8.

Sinex, F. M., McMullen, J. \& Hastings, A. B. (1952). F. biol. Chem. 198, 615.

Snedecor, G. W. (1946). Statistical Methods, $4^{\text {th }}$ ed. Ames: Iowa State College Press.

Thomson, W. S. T. \& Munro, H. N. (1955). F. Nutr. 56, 139.

Whipple, G. H., Hooper, C. W. \& Robscheit, F. S. (1920). Amer. F. Physiol. 53, 167.

Young, L., Edson, M. \& McCarter, J. A. (1949). Biochem. F. 44, 179.

Zittle, C. A. \& O'Dell, R. A. (194I). F. biol. Chem. 139, 753.

\title{
The composition of tissue lost through reduction of diet in obese patients
}

\author{
By H. LJUNGGREN, D. IKKOS AND R. LUFT \\ Department of Endocrinology, Karolinska sjukhuset, Stockholm
}

(Received 22 April 1959-Revised 23 fuly 1959)

'Obesity tissue' has been defined as the tissue gained as a result of overeating (Keys \& Brožek, I953) and its composition has been estimated in various ways (Brožek \& Keys, I955; Johnston \& Bernstein, 1955; Keys, Anderson \& Brožek, I955; Passmore, Meiklejohn, Dewar \& Thow, 1955; Ljunggren, Ikkos \& Luft, 1957b). It has been assumed that the tissue lost by obese people on a reducing regimen is of a similar composition (Keys \& Brožek, I953; Ljunggren, 1957). In the present study the composition of obesity tissue lost by people on a reducing regimen was estimated from the changes in total and extracellular body water and exchangeable potassium.

\section{EXPERIMENTAL}

Subjects and procedure. Seven patients, five females 'and two males, being treated for obesity as out-patients, were studied. None showed signs of cardiac insufficiency, disturbances of water and electrolyte metabolism, or abnormal thyroid function. Their ages, body-weights and heights are shown in Table $\mathbf{I}$.

The measurements were taken before and after restriction of calorie intake by means of a prescribed diet containing about $800 \mathrm{kcal} /$ day. All patients were given amphetamine to allay hunger, and five were also given a small dose of desiccated thyroid.

The interval between the two measurements varied from 80 to 303 days (Table 1 ).

Estimation of body water and potassium. Total body water was estimated as the volume of distribution of deuterium oxide (Ljunggren, 1955). Extracellular water was 